\title{
Determination of hygienic status of refrigerators surface
}

\section{Gamze DÜVEN ${ }^{1,2}$, Gülten TÍRYAKİ GÜNDÜZ ${ }^{1}$, Duygu KIŞLA ${ }^{1}$}

Cite this article as:

Düven, G., Tiryaki Gündüz, G., Kışla, D. (2021). Determination of hygienic status of refrigerators surface. Food and Health, 7(4), 251-258.

https://doi.org/10.3153/FH21026

${ }^{1}$ Ege University, Faculty of Engineering, Department of Food Engineering, 35100 Izmir, Turkey

${ }^{2}$ Bursa Uludag University, Karacabey Vocational School, Department of Food Processing, 16700, Bursa, Turkey

RCID IDs of the authors:

G.D. 0000-0001-7418-5384

G.T.G. 0000-0002-5878-7411

D.K. 0000-0002-6993-3883

Submitted: 26.01 .2021

Revision requested: 30.03 .2021

Last revision received: 10.04 .2021

Accepted: 15.04 .2021

Published online: 02.08 .2021

Correspondence:

Gamze DÜVEN

E-mail: gamzeduven@uludag.edu.tr

\begin{abstract}
This study was aimed to determine the microbial load and the hygienic status of household refrigerator surfaces. Psychrotrophic and coliform bacteria counts were carried out to determine the hygienic status of household refrigerators. Surface samples were investigated in 3 groups as housewives', students' and workers' refrigerators, and each group, including ten refrigerators. A total of two hundred and forty samples, one hundred and twenty sides and one hundred and twenty shelves were taken from the side and shelf surfaces of a total of thirty different refrigerators. In general, when the results were examined, it was determined that the sanitation program and effectiveness of the workers' refrigerators were sufficient, and the sanitation of the housewives' and students' should be examined or insufficient.
\end{abstract}

Keywords: Refrigerator, Hygiene, Psychrothropic bacteria, Coliform bacteria

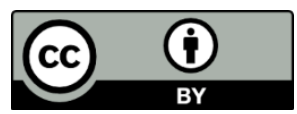

(C) 2021 The Author(s)

Available online at http://jfhs.scientificwebjournals.com 


\section{Introduction}

Today, consumers' expectations from the food industry are increasing day by day. Consumers are attentive and conscious recently, and they increase their selectivity in using materials in contact with foods such as packaging materials, storage boxes, and refrigerators' surfaces. Although cold storage is known as one of the oldest and commonly used food preservation methods, the sanitary condition of household refrigerators is also extremely important for public health all over the world (Ayaz Topçu et al., 2003). In Europe, 32.7\% of outbreaks of foodborne illnesses occur due to improper practices and lack of hygiene during food preparation at home (EFSA, 2013).

The most recommended average operating temperature of refrigerators used for storing food in the cold is between $1{ }^{\circ} \mathrm{C}$ to $4^{\circ} \mathrm{C}$ (WHO, 2001; FDA, 2014; FSA, 2015). This temperature range inhibits the growth of many microorganisms responsible for food spoilage and foodborne illnesses. However, many household refrigerators are incorrectly adjusted and operated above recommended temperature (Evans et al., 1991; Nauta et al., 2003; Rahman et al., 2005; Peck et al., 2006; Gilbert et al., 2007; Godwin et al., 2007; Vegara et al., 2014; James et al., 2016). So, the refrigerators become a secret habitat for mesophilic organisms such as Staphylococcus aureus and Salmonella spp. (Flynn, Blair, \& McDowell, 1992; Johnson et al., 1998; V. Jackson et al., 2007). Even when correctly adjusted, psychrotroph pathogens, such as Listeria monocytogenes, Yersinia enterocolitica, and Aeromonas hydrophila, can grow at refrigerator temperatures. Also, psychrotrophic bacteria (Pseudomonas, Acinetobacter, Flavobacterium, and Alcaligenes, etc.) and fungi belonging to the genus of Penicillium, Mucor, Cladosporium, and Botrytis cause spoilage in food kept at refrigerator temperature. (Göktan and Tunçel, 2010).

The other important issue about the refrigerator's temperature is its fluctuation behavior (James et al., 2016). Generally, the excessive frequent and long-time door opening cause decreasing the temperature performance of a household refrigerator. It was found that 17 out of 104 refrigerators were opened less than ten times a day, 39 refrigerators were opened 10-20 times a day, and 44 refrigerators more than 20 times a day. Also, the refrigerator temperatures were higher in refrigerators with a high frequency of door openings (Saidur et al., 2008).

The refrigerators are essential equipment to store foods. For the food safety, the hygienic status of this equipment plays a vital role, food residues may help the growth of microorganisms, and this makes the refrigerators to be a secret habitat for microorganisms (Ilg et al., 2011). Many people think that microorganisms cannot survive in the refrigerator, but this is a misconception. Listeria innocua was found in one refrigerator's inner wall of the vegetable compartment out of 60 refrigerators (Dieuleveux, Collobert, Dorey, \& Guix, 2005; Catellani et al., 2014). In Ireland, several foodborne pathogens such as Staphylococcus aureus, Salmonella spp., Listeria monocytogenes, and Yersinia enterocolitica was isolated varying in number from $2 \%$ to $40 \%$ of the refrigerators sampled (Bolton et al., 2005; Catellani et al., 2014).

Also, many people do not often implement the good hygienic practices (GHPs) rigorously despite having some knowledge of hygiene in the handling and cold storage of the food (Catellani et al., 2014). It was shown in a study that only $16 \%$ of refrigerator users clean their refrigerators once a month or more frequently; $51.1 \%$ of users clean twice or four times in a year and $5.6 \%$ of users do not clean their refrigerators (Ilg et al., 2011). Considering that houses are also a small food factory, GHP is very important and necessary for food safety and hygiene.

It should be paid attention to the hygiene of the refrigerators to the adequate temperature control and thorough and to the regular cleaning of household refrigerators for the safety and long period storage of foods. Notably, the interior surfaces of household refrigerators are at risk of becoming contaminated with foodborne pathogens, increasing the chances of crosscontamination to other food items, including higher risk ready-to-eat foods.

As a result, the household refrigerators are a notable element in terms of prevention of food spoilage, food poisoning, and lack of GHPs in the domestic kitchen.

In Turkey, detailed investigations on the hygienic status of the household refrigerators have never been conducted to date. This research aims to fill this gap in knowledge.

\section{Materials and Methods}

\section{Refrigerator Selection}

The refrigerator samples were investigated in 3 groups, including housewives', students' and workers' refrigerators, and each group includes ten refrigerators. Thirty different refrigerators' shelf and side surfaces were sampled by the swab method in 2-month periods in full eight months. Totally 120 shelf and 120 side surface samples were collected for this study. The samples were transported to the laboratory in a cold box in a maximum time of $2 \mathrm{~h}$ and were analyzed immediately after their arrival. 


\section{Sample Collection}

Sterile paper template (with $5 \times 5 \mathrm{~cm}^{2}$ middle space) was placed aseptically on the refrigerator surface (Figure 1). Samples were taken from two different shelves and two different sides (opposite inner walls) surfaces of refrigerators by the swab method. Sterile swab sticks were wetted by $\% 0.1$ sterile PW before sampling. Swab sticks containing two different shelf samples from the same refrigerator were transferred 10 $\mathrm{ml}$ sterile peptone water and swab sticks containing two different side samples from the same refrigerator were transferred $10 \mathrm{ml}$ sterile PW.

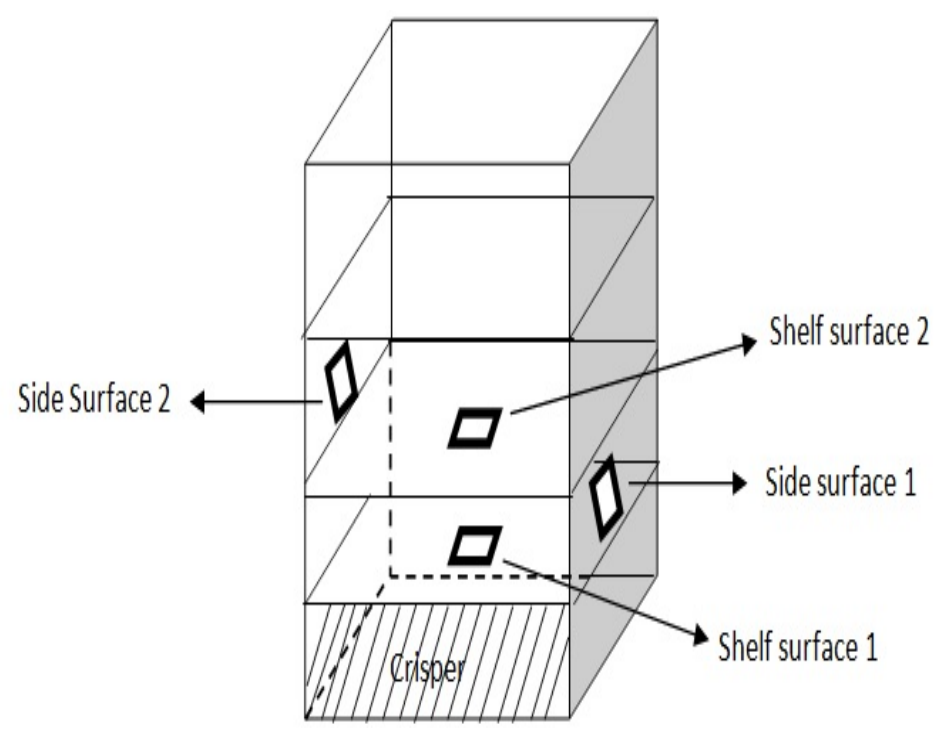

Figure 1. Side and shelf surface samples taken from refrigerators

\section{Microbiological Analysis}

The tubes containing samples were vortexed for 30 seconds. Decimal solutions were prepared from the samples. For total psychrotrophic bacteria count, the pour plate method was used in PCA and incubated at $7^{\circ} \mathrm{C}$ for ten days (AOAC, 1984). CCA was used for the determination of coliform count by the spread plate method. After incubation at $37^{\circ} \mathrm{C}$ for $24-$ 48 hours, salmon to red colour colonies were counted as coliform colonies. E. coli is selected from other coliforms by creating a dark blue-violet colour colony. The indole test was performed for the dark blue-violet colonies on CCA, and positive results of the indole test were counted as E.coli (Halkman ve Sağdaş, 2011).

\section{Statistical Analyses}

Statistical analyses were performed with IBM SPSS Statistics 20 software (USA). Independent samples t-test was performed to determine the significance between the refrigerator and significance levels as $p<0.05$.

\section{Results and Discussion}

\section{Total Psychrotrophic Bacteria Count (TPBC)}

There is no unique microbiological criterion to assess refrigerator surfaces' sanitation program and efficiency. The inner surface of domestic refrigerators can be linked to the work surface in the food industry. The criteria for the hygienic status of devices and equipment surfaces in a food plant reported by Harrigan et al. (1998) were used in the study (Table1). Based on the criteria listed in Table1, we evaluated the surface samples of refrigerators, as summarized in Table2.

TPBC were found as less than $5 \mathrm{CFU} / \mathrm{cm}^{2}$ in 30 samples $(75.0 \%), 5-25 \mathrm{CFU} / \mathrm{cm}^{2}$ in 6 samples $(15.0 \%)$, greater than $25 \mathrm{CFU} / \mathrm{cm}^{2}$ in 4 samples $(\% 10.0)$ from housewifes' refrigerators shelf surfaces. TPBC were observed less than $5 \mathrm{CFU}$ $/ \mathrm{cm}^{2}$ in 38 samples $\left(95.0 \%\right.$ ), greater than $25 \mathrm{CFU} / \mathrm{cm}^{2}$ in 2 samples $(5.0 \%)$ from students' refrigerators shelf surfaces. TPBC were detected as less than $5 \mathrm{CFU} / \mathrm{cm}^{2}$ in 38 of $40 \mathrm{sam}-$ ples $(95.0 \%)$, as $5-25 \mathrm{CFU} / \mathrm{cm}^{2}$ in 1 out of 40 samples (2.5\%), as more than $25 \mathrm{CFU} / \mathrm{cm}^{2} 1$ out of 40 samples $(2.5 \%)$ (Table 2).

Forty $(100.0 \%)$ housewives side surface samples counting results were determined as less than $5 \mathrm{CFU} / \mathrm{cm}^{2} \mathrm{TPBC}$. The students' refrigerators side surface samples were as less than $5 \mathrm{CFU} / \mathrm{cm}^{2}$ in 39 samples $(97.5 \%), 5-25 \mathrm{CFU} / \mathrm{cm}^{2}$ in a sample $(2.5 \%)$ (Table 2). TPBC was detected as less than 5 $\mathrm{CFU} / \mathrm{cm}^{2}$ in 40 (100.0 \%) workers' side surface samples.

These results show that shelf surfaces are more contaminated than the side surfaces of refrigerators. There was no significant difference between students' and workers' refrigerators shelf surface's sanitation program and efficiency level when they were compared to each other $(p>0.05)$. Moreover, the housewives' shelf surface samples observed the most contaminated surface samples $(p<0.05)$.

However, students' refrigerators side surface's sanitation program and efficiency were found to be significantly different from housewives', and workers' refrigerators side surface's one $(p<0.05)$. According to statistical analyses, no significant difference between housewives' and workers' refrigerators side surface's sanitation program and efficiency level was observed $(p>0.05)$. 
Table 1. Criteria for assesing the total viable count on devices and equipment surfaces (Harrigan, 1998).

\begin{tabular}{|c|l|}
\hline Total Viable Counts $\left(\mathbf{C F U} / \mathbf{c m}^{\mathbf{2}}\right)$ & \multicolumn{1}{c|}{ Assessment } \\
\hline$<\mathbf{5}$ & Sanitation programs and efficiency is sufficient \\
\hline $\mathbf{5 - 2 5}$ & Sanitation programs and efficiency should be examined (Reviewable) \\
\hline$>\mathbf{2 5}$ & Sanitation programs and efficiency is insufficient \\
\hline
\end{tabular}

The number of coliforms: Equipment used for food transport and delivery and container is put on thermal processing food must have less than 10 number of bacteria per $100 \mathrm{~cm}^{2}$. Any coliform per $100 \mathrm{~cm}^{2}$ is ideal.

Table 2. Sanitation programs and efficiency assessment of the refrigerator's samples for total psychrotroph count according to Harrigan, 1998.

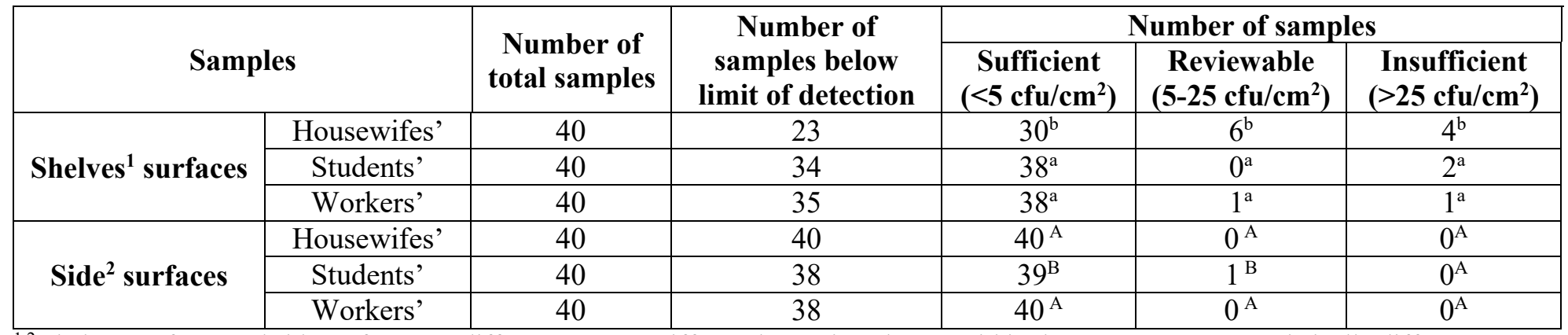

${ }^{1,2}$ Shelves surfaces and side surfaces are different groups. Different letters in columns within the same group are statistically different $(p<0.05)$.

Hygenic status of housewives' refrigerators was observed the more contaminated one than other samples. This situation could be that the housewives' use refrigerators more often than students' and workers' in a day, and it causes excessive air circulation and temperature fluctuations in refrigerators. Another reason could be the housewives' incorrect habits in refrigerators cleaning. Similarly, Ateş et al. (1986) indicated that homemakers made improper applications, especially in food preparation, cooking, and the thawing stage (Ayaz Topçu et al., 2003). As Carpentier et al. (2012) reported that consumers should avoid condensation resulting from temperature fluctuation and clean food residues as soon as possible to achieve clean and hygienic refrigerator surfaces. In a study performed in Greece, the temperature pattern in the refrigerators was investigated, and it was found that $55 \%$ of the 136 domestic and $32 \%$ of the 228 retail store refrigerators had temperatures of greater than or equal to $9^{\circ} \mathrm{C}$ (Sergelidis et al., 1997). In another study performed in Portugal, $71 \%$ were operating at a temperature higher than $6.1^{\circ} \mathrm{C}, 87 \%$ were cleaned only monthly or less frequently, and only $8 \%$ were cleaned with appropriate and particular cleaning products available in supermarkets. It was determined that $\% 35$ attendants stored vegetables and $\% 28$ attendants stored fermented meat without packaging in their refrigerator (Azevedo et al., 2005). It is clear from the published data that many domestic refrigerators working temperatures throughout the world are higher than the recommended temperature $\left(0\right.$ to $8^{\circ} \mathrm{C}$ or meanly $\left.4{ }^{\circ} \mathrm{C}\right)$ (James et al., 2016).

Moreover, householders are unaware of their refrigerator operating temperature and the recommended (Duric et al., 2013; James et al., 2016). As seen in these studies, the inside temperature of refrigerators depends on the usage frequency of refrigerators. These temperature fluctuations and inadequate hygiene practices promote microorganisms' growth in the refrigerator surfaces, which is already contaminated in different ways.

It was shown that refrigerators' shelf surfaces require a more effective sanitation program than side surfaces of refrigerators. It was reported that refrigerator surfaces could be contaminated from a variety of sources such as direct contact with food, the hands of the consumers, air or contaminated dishcloths, leaking packages, unclean container surfaces, unwashed raw foods (Toule and Murphy, 1978; Enriquez et al., 1997; Gorman et al., 2002; De Jong et al., 2008; Ilg et al., 2011; Macias-Rodriguez et al., 2013). Vegetables and fruits have high microbial loads because they are often directly in contact with soil. Therefore, vegetables and fruits can easily contaminate the refrigerators' surface if they stored unwashed and unpackaged (Jackson et al., 2007; Jeon et al., 2013). For that reason, food storage without packaging and unwashed in a refrigerator is an incorrect application (Macias-Rodriguez et al., 2013). 
Catellani et al. (2014) investigated microbial contamination levels of domestic refrigerators in Italy. They analyzed 293 domestic refrigerators of students and workers. Sponge bags sampled two internal surfaces for each refrigerator. Slightly above $50 \%$ of the samples' total viable count was greater than $1 \log \mathrm{CFU} / \mathrm{cm}^{2}$. The number of microorganisms at the refrigerator's bottom surface was significantly higher than at the side surface. Mould counts were greater than $1 \log \mathrm{CFU} / \mathrm{cm}^{2}$ in 86 samples ( 61 bottom samples and 25 side surface samples). Yeast counts were determined as $\geq 2.5 \log \mathrm{CFU} / \mathrm{cm}^{2}$ in 28 samples. Pseudomonas spp. $\left(>10 \mathrm{CFU} / \mathrm{cm}^{2}\right)$ in 77 samples, Aeromonas spp. $\left(>10 \mathrm{CFU} / \mathrm{cm}^{2}\right)$ in 26 samples, Bacillus cereus in 18 samples, coagulase-positive staphylococci in 13 samples, Salmonella spp. in 8 samples were found. Listeria monocytogenes and Yersinia enterocolitica were never observed in the study. The results show that refrigerator surfaces, especially shelves surfaces, could be a secret habitat for microorganisms. So, it is essential to clean the household refrigerator regularly and using appropriate disinfection procedures.

\section{Total Coliform Bacteria Count (TCBC)}

TCBC were found as $2 \mathrm{CFU} / \mathrm{cm}^{2}$ in a housewives' refrigerators shelf surface sample. These coliform bacteria were determined as E.coli by Indole test. No coliform bacteria were observed other shelf and side surface samples of refrigerators except two students' refrigerators side surface sample. In one of these two samples, eight $\mathrm{CFU} / \mathrm{cm}^{2}$ coliform bacteria were detected. The Indol test of the coliform bacteria was negative. In the other students' refrigerators side sample, $3.26 \times 10^{2}$
$\mathrm{CFU} / \mathrm{cm}^{2}$ coliform bacteria were detected, and these coliform bacteria were found as susceptible to be E.coli (Table 3).

According to Table1, equipment used for food transport and delivery and container is put on thermal processing food must have less than 10 number of bacteria per $100 \mathrm{~cm}^{2}$. Any coliform per $100 \mathrm{~cm}^{2}$ is ideal. Therefore, 1 out of 40 housewives' refrigerators shelf surface sample samples and 2 out of 40 students' refrigerators shelf surface sample samples hygienic status could be evaluated as "insufficient."

In our study, students' refrigerators were more contaminated with coliform bacteria than housewives' and workers' refrigerators. It could be said that samples in which their sanitation program and efficiency were found to be "insufficient" to coliform bacteria also count their sanitation program, and efficiency was found insufficient for psychotropic bacteria count. In a study in Iran, the contamination level of Listeria spp. in household refrigerators were determined. For this purpose, 180 refrigerators in student accommodations and private houses were sampled by swab, and their temperature was measured before sampling. L.monocytogenes was present in a student's refrigerator. L.innocua was also isolated from two refrigerators. In general, students are careless about their refrigerator cleaning, and they put foods unwrapped in a refrigerator. These careless and wrong practices could cause increasing in microbial load on the surface of the refrigerator. The students' refrigerators' temperature was also observed higher than private houses' refrigerators (Maktabi et al., 2013).

Table 3. Sanitation programs and efficiency assessment of the refrigerator's samples for total coliform count according to Harrigan (1998).

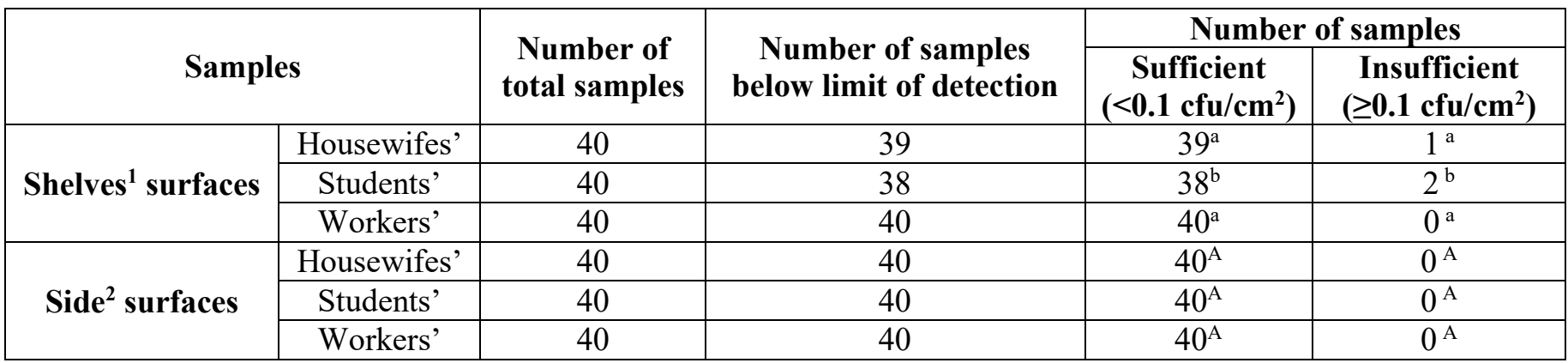

${ }^{1,2}$ Shelves surfaces and side surfaces are different groups. Different letters in columns within the same group are statistically different $(p<0.05)$. 
In a study performed Ireland, the number of significant foodborne pathogens and the general hygienic status (as estimated by total viable counts (TVCs) and total coliform counts (TCCs)) on the inner surfaces (base, shelves, and sides) of domestic refrigerators was investigated. Campylobacter spp., Salmonella spp., and Escherichia coli O157: H7 was not observed from any refrigerators, but Staphylococcus aureus was determined 6.4\%, Listeria monocytogenes, and E.coli as $1.2 \%$ and Yersinia enterocolitica as $0.6 \%$ of refrigerators. TVCs were ranged from $2.91 \log \mathrm{CFU} / \mathrm{cm}^{2}$ to $8.78 \mathrm{log} \mathrm{CFU} / \mathrm{cm}^{2}$ and TTCs were ranged from $0.045 \mathrm{log}$ $\mathrm{CFU} / \mathrm{cm}^{2}$ to $5.96 \log \mathrm{CFU} / \mathrm{cm}^{2}$. It shows consumer refrigerator management and hygiene's inferior standards and poses risks to consumer health (Jackson et al. (2007). Macias-Rodriguez et al. (2013) stated that the mean of coliform counts on refrigerator surfaces was similar to those reported in other studies such as Kennedy et al. (2005) and Jackson et al. (2007). Coliform contamination in refrigerators could be increased by storing contaminated foods, especially with soil (such as vegetables and fruits) and by poor cleaning frequency of food, by contact with unclean hands of consumers or improper practices in the kitchen (James et al., 2016).

\section{Conclusion}

In conclusion, our investigation has allowed us to ascertain that:

1. the applied sanitation program to refrigerators is not enough especially for housewives' and students' refrigerators,

2. shelf surfaces are more contaminated from side surfaces,

3. E.coli existence was determined in the case of insufficient sanitation at refrigerator surfaces.

Thus, the hygiene of a refrigerator used for the conservation of food became a crucial subject. It was observed that the users did not seem aware of refrigerator hygiene and recommended the operating temperature of the refrigerator. Most of them were keeping their food unpacked or unwashed in the refrigerator and were overfilling their refrigerators. Also, factors such as temperature fluctuations and a high amount of air circulation are lead to an increase in microbial load, whereas the usage of a refrigerator. It is essential to clean the refrigerator more frequently and using appropriate disinfection procedures.

\section{Compliance with Ethical Standard}

Conflict of interests: The author declares that for this article they have no actual, potential or perceived conflict of interests.

Ethics committee approval: The authors declare that this study does not require ethical permission.

Funding disclosure: TUBITAK supported this study with the 2241-A Industry Focused Undergraduate Thesis Support Programme.

Acknowledgments: We owe our thanks to TUBITAK (The Scientific and Technological Research Council of Turkey) for financial support and Ege University Head of Food Engineering Department, Prof. Dr. Duygu KIŞLA, Assoc Prof. Dr. Gülten TİRYAKİ GÜNDÜZ, and Vestel Beyaz Eşya Sanayi ve Ticaret A.Ş. for spiritual help while winning this support.

Disclosure: This study was done as an undergraduate thesis.

\section{References}

AOAC International. (1984). The Official Methods of Analysis, Chapter 8: Psychrotrophic Microorganisms, AOAC International, Gaithersburg, MD. ISBN: 9780935584240

Ateş, M., Ballar, E., Pekcan, G. (1986). Sosyo-ekonomik yönden farklı semtlerde yaşayan ev kadınlarının besin hazırlama, pişirme, saklama yöntemlerinin saptanması, Beslenme ve Diyet Dergisi, 15, 71-83.

Ayaz Topçu, A., Köksal, E., Bilgili, N. (2003). 15-49 yaş grubu ev hanımlarının besin hazırlama, pişirme ve saklama yöntemleri konusunda bilgi, tutum ve davranışlarına yönelik bir araştırma, Türk Hijyen ve Deneysel Biyoloji Dergisi, 60(3), 77-86.

Bolton, D.J., Kennedy, J., Cowan, C. (2005). Irish domestic food safety knowledge, practice and microbiology with particular emphasis on Staphylococcus aureus. Ashtown, Dublin, Ireland, the National Food Centre, ISBN: 1841704024.

Carpentier, B., Lagendijk, E., Chassaing, D., Rosset, P., Morelli, E., Noël, V. (2012). Factors impacting microbial load of food refrigeration equipment. Food Control, 25, 254259.

https://doi.org/10.1016/j.foodcont.2011.10.051

Catellani, P., Miotti-Scapin, R., Alberghini, L., Radu, I.L., Giaccone, V. (2014). Levels of microbial contamination of domestic refrigerators in Italy. Food Control, 42, 257-262. https://doi.org/10.1016/j.foodcont.2014.02.025 
De Jong, A.E.I., Verhoeff-Bakkenes, L., Nauta, M.J., De Jonge, R. (2008). Cross contamination in the kitchen: effect of hygiene measures. Journal of Applied Microbiology, 105, 615-624.

https://doi.org/10.1111/j.1365-2672.2008.03778.x

Duric, J., Ivanovic, J., Loncina, J., Sarcevic, D., Dordevic, V., Boskovic, M., Baltic, M.Z. (2013). Examination about consumers' knowledge of food storage conditions in household- context of food safety. Proceedings of International $57^{\text {th }}$ Meat, Industry Conference, Belgrad, June $10^{\text {th }}-12^{\text {th }}, 247-$ 252. ISBN: 9788682547075

Dieuleveux, V., Collobert, J., Dorey, F., Guix, E. (2005). Surveillance de la contamination par Listeria spp de réfrigérateurs. Science de l'Alimentation, 25(2), 147-155.

https://doi.org/10.3166/sda.25.147-155

Enriquez, C.E., Enriquez-Gordillo, R., Kennedy, D.I., Gerba, C.P. (1997). Bacteriological survey of used cellulose sponges and cotton dishcloths from domestic kitchens. Dairy, Food and Environmental Sanitation, 17, 20-24.

Evans, J. A., Stanton, J. I., Russell, S. L., James, S. J. (1991). Consumer handling of chilled foods: A survey of time and temperature conditions. MAFF Publications, London PB 0682 .

Flynn, O.M.J., Blair, I., McDowell, D. (1992). The effciency and consumer operation of domestic refrigerators. International Journal of Refrigeration, 15(5), 307-312.

https://doi.org/10.1016/0140-7007(92)90046-W

Food Standards Agency [FSA]. (2015). Chilling. Retrieved from https://www.food.gov.uk/safety-hygiene/chilling (accessed 20.7.2021)

Gilbert, S.E., Whyte, R., Bayne, G., Lake, R.J., van der Logt, P. (2007). Survey of internal temperatures of New Zealand domestic refrigerators. British Food Journal, 109, 323329.

https://doi.org/10.1108/00070700710736570

Godwin, S.L., Chen, F.C., Chambers IV, E., Coppings, R., Chambers, D. (2007). A comprehensive evaluation of temperatures within home refrigerators. Food Protection Trends, 27(3), 168-173.

Gorman, R., Bloomfield, S., Adley, C. (2002). A study of cross contamination of food-borne pathogens in the domestic kitchen in the republic of Ireland. International Journal of Food Microbiology, 76, 143-150.

https://doi.org/10.1016/S0168-1605(02)00028-4

Göktan, D., Tunçel, G. (2010). Gıda Hijyeni-I. Meta Basım Matbaac1lı Hizmetleri, İzmir, pp. 111-114. ISBN: 9786055267339

Halkman, A.K., Sağdaş, Ö.E. (2011). Merck Mikrobiyoloji El Kitabı (Hızlı Erişim). Ankara, 2: pp 234, Retrieved from http://www.mikrobiyoloji.org/TR/pdf/merckmikrobiyoloji_elkitabi.pdf (accessed 14.03.2014).

Harrigan, W.F. (1998). Laboratory Methods in Food Microbiology. Academic Press, pp. 308. ISBN: 9780123260437

Ilg, Y., Bruckner, S., Kreyenschmidt, J. (2011). Applicability of surfaces containing silver in domestic refrigerators. International Journal of Consumer Studies, 35, 221-227. https://doi.org/10.1111/j.1470-6431.2010.00976.x

Jackson, V., Blair, I.S., McDowell, D.A., Kennedy, J., Bolton, D.J. (2007). The incidence of significant foodborne pathogens in domestic refrigerators. Food Control, 18, 346https://doi.org/10.1016/j.foodcont.2005.10.018

James, C., Onarinde, B.A., James, S.J. (2016). The use and performance of household refrigerators: a review. Comprehensive Reviews in Food Science and Food Safety, 16, 160179.

https://doi.org/10.1111/1541-4337.12242

Jeon, Y., Chun, J., Kim, B. (2013). Identification of household bacterial community and analysis of species shared with human microbiome Current Microbiology, 67, 557-563. https://doi.org/10.1007/s00284-013-0401-y

Johnson, A.E., Donkin, A.J.M., Morgan, K., Lilley, J.M., Neale, R.J., Page, R.M., Silburn, R. (1998). Food safety knowledge and practice among elderly people living at home. Journal of Epidemiology and Community Health, 52(11), 745-748.

https://doi.org/10.1136/jech.52.11.745

Kennedy, J., Jackson, V., Blair, I.S., McDowell, D.A., Cowan, C., Bolton, D.J. (2005). Food safety knowledge of consumers and the microbiological and temperature status of their refrigerators. Journal of Food Protection, 68, 14211430.

https://doi.org/10.4315/0362-028X-68.7.1421 
Macias-Rodriguez, M.E., Navarro-Hidalgo, V., LinaresMorales, J.R., Olea-Rodriguez, M.A., Villarruel-Lopez, A., Castro-Rosas, J., Gomez-Aldapa, C.A., Torres-Vitela, M.R. (2013). Microbiological safety of domestic refrigerators and the dischloths used to clean them in Guadalajara, Jalisco, Mexico. Journal of Food Protection, 76(6), 984-990. https://doi.org/10.4315/0362-028X.JFP-12-258

Maktabi, S., Jamnejad A., Faramarzian, K. (2013). Contamination of household refrigerators by Listeria species in Ahvaz, Iran. Jundishapur Journal of Microbiology, 6(3), 301-305.

https://doi.org/10.5812/jjm.3543

Nauta, M.J., Litman, S., Barker, G.C., Carlin F. (2003). A retail and consumer phase model for exposure assessment of Bacillus cereus. International Journal of Food Microbiology, 83, 205-218.

https://doi.org/10.1016/S0168-1605(02)00374-4

Peck, M.W., Goodburn, K.E., Betts, R.P., Stringer, S.C. (2006). Clostridium botulinum in vacuum packed (VP) and modified atmosphere packed (MAP) chilled foods. Final Project Report July 2006 (FSA Project B13006), Institute of Food Research, Norwich, U.K. https:/quadram.ac.uk/wpcontent/uploads/2017/07/Final_project_report0707.pdf (accessed 29.07.2021)

Rahman, S., Sidik, N.M., Hassan, M.H., Rom, T.M., Jauhari, I. (2005). Temperature performance and usage conditions of domestic refrigerator-freezers in Malaysia. HKIE Transactions, 12(2), 30-35.

https://doi.org/10.1080/1023697X.2005.10668000
Saidur, R., Masjuki, H.H., Hasanuzzaman, M., Kai, G.S. (2008). Investigation of energy performance and usage behavior of domestic refrigerator freezer using clustering and segmentation. Journal of Applied Science, 8, 3957-3962.

https://doi.org/10.3923/jas.2008.3957.3962

Sergelidis, D., Abrahim, A., Sarimvei, A., Panoulis, C., Karaioannoglou, P., Genigeorgis, C. (1997). Temperature distribution and prevelance of Listeria spp. in domestic, retail and industrial refrigerators in Greece. International Journal of Food Microbiology, 34, 171-177.

https://doi.org/10.1016/S0168-1605(96)01175-0

Toule, G., Murphy, O. (1978). A study of bacteria contaminating refrigerated cooked chicken, their spoilage potential and possible origin. Journal of Hygiene, 81, 161-169. https://doi.org/10.1017/S0022172400024980

USA Food and Drug Administration [FDA]. (2014). Are you storing food safely? Consumer health information handout. US Food and Drug Administration, April 2014. Retrieved from: http://www.fda.gov/ForConsumers/ConsumerUpdates/ucm093704.htm (accessed 01.05.2016).

Vegara, A., Festino, A.R., Ciccio, P.D., Costanzo, C., Pennisi. L., Ianieri, A. (2014). The management of the domestic refrigeration: microbiological status and temperature. British Food Journal, 116, 1047-1057.

https://doi.org/10.1108/BFJ-05-2012-0103

World Health Organization [WHO]. (2001). Five keys to safer food. Geneva, Switzerland: World Health Organization. Retrieved from https://www.who.int/foodsafety/publications/consumer/manual keys.pdf (accessed 29.07.2021). 